\title{
Pengaruh Senam Kegel Terhadap Kesiapan Diri Secara Seksual Ibu Primipara Di Rumah Sakit Umum Bangli Medika Canti Bali Tahun 2019
}

\author{
Cholisah Suralaga*, Luh Ayu Mas Krisnadewi, Sri Dinengsih \\ Fakultas Ilmu Kesehatan, Universitas Nasional, Jakarta, Indonesia \\ Corresponding author: Cholisah Suralaga (cholisah.suralaga@ civitas.unas.ac.id) \\ Received: Mei, 16 2020; Accepted: June, 13 2020; Published: September, 12020
}

\begin{abstract}
ABSTRAK
Tingkat kepuasan seksual pada masyarakat di Indonesia termasuk pada kelompok yang rendah dibandingkan negara-negara yang lain. Rendahnya tingkat kepuasan seksual ini meningkat pada ibu pascapersalinan akibat penurunan kesiapan diri secara seksual yang terjadi karena kehamilan, proses melahirkan dan adaptasi masa nifas. Latihan kegel secara teratur pasca melahirkan dapat membantu mempercepat proses involusi organ reproduksi sehingga mempengaruhi kesiapan seksual ibu pascamelahirkan. Penelitian quasi-experiment ini menggunakan rancangan non-equivalent control group design. Sampel dalam penelitian ini berjumlah $32 \mathrm{ibu}$ primipara yang terdiri dari $16 \mathrm{ibu}$ kelompok perlakuan dan $16 \mathrm{ibu}$ kelompok kontrol. Teknik pengambilan sampel menggunakan metode restriksi. Instrumen penelitian adalah kuesioner tentang indeks fungsi seksual wanita. Kuesioner ini telah diuji validitas dan reliabilitas pada penelitian sebelumnya dengan nilai semua domain yaitu $r=0.79-0.86$. Data dianalisis menggunakan statistik deskriptif dan statistik inferensial yaitu wilcoxon untuk mengetahui perbedaan skor kesiapan seksual dalam satu kelompok dan mann withney untuk mengetahui perbedaan skor kesiapan seksual antar kelompok. Terdapat pengaruh yang signifikan kesiapan seksual primipara yang melakukan latihan kegel nilai Asymp. Sig 0,009 < $\alpha(0,05)$ dengan rerata kelompok perlakuan 20,84 dan kelompok kontrol 12,16. Latihan kegel memiliki pengaruh terhadap kesiapan diri secara seksual ibu primipara. Ibu primipara dengan latihan kegel lebih siap untuk memulai kembali kehidupan seksualnya pasca melahirkan.
\end{abstract}

Kata Kunci: Latihan kegel, kesiapan seksual, primipara

This is an open-acces article distributed under the terms of the Creative Commons Attribution-ShareAlike 4.0 International License.

\section{PENDAHULUAN}

Hubungan intim setelah melahirkan merupakan hal yang kompleks karena perubahan kesehatan seksual yang terjadi pada periode ini merupakan bentuk adaptasi dengan peran baru sebagai ibu dan ayah(Asselmann et al., 2016). Bagi ibu yang mengalami persalinan untuk pertama kalinya (primipara), terjadi perubahan yang sangat bermakna dalam hidupnya secara fisik dan psikologis (Prawirohardjo, 2010) Salah satu perubahan yang ibu nifas akan alami adalah penurunan fungsi seksual, sehingga hasrat seksual ibu lebih rendah dibanding pasangannya (Leeman \& Rogers, 2012) Kesiapan diri secara seksual (sexual self-efficacy) pada 
ibu setelah persalinan adalah salah satu cara untuk memahami kesehatan psikologis ibu dalam respon seksual yang sehat. Kepuasan dalam pernikahan termasuk kesiapan diri secara seksual merupakan variabel yang tidak tampak namun penting dalam fungsi seksual individu. Sexual self-efficacy yang rendah dan tidak adanya kepercayaan pada kemampuan mereka dalam aktivitas seksual setelah melahirkan menciptakan masalah dalam pemilihan dan penerimaan perilaku dan fungsi seksual yang tepat.

Kehamilan dan persalinan membawa banyak perubahan pada kesehatan dan kesejahteraan ibu primipara. Perubahan hormon serta kekuatan mekanik selama kehamilan dan juga tekanan proses persalinan pada otot dasar panggul dapat memberikan kerusakan saraf dan otot pada organ dasar panggul yang menyebabkan gangguan seksual lebih lanjut. Pada perempuan yang telah melewati kehamilan, otot dasar panggul biasanya melemah. Kelemahan otot dasar panggul memberikan stimulasi gairah tidak adequate, sehingga menghambat potensi orgasme. Salah satu alternatif untuk mengembalikan fungsi seksual wanita postpartum yaitu dengan senam kegel karena dapat membantu memperbaiki sirkulasi darah, memperbaiki sikap tubuh setelah hamil dan melahirkan, memperbaiki tonus otot pelvis dan otot vagina, memperbaiki regangan otot tungkai bawah dan memperkuat otot-otot dasar perut dan dasar panggul(Ferreira et al., 2015). Melakukan latihan ini menyebabkan revaskularisasi sel dan jaringan yang rusak (Adel et al. 2010 ).

Begitu banyak manfaat yang bisa didapatkan dengan melakukan senam kegel pascamelahirkan sehingga penelitian ini bertujuan untuk mengetahui pengaruh latihan kegel terhadap kesiapan diri secara seksual ibu primipara.

\section{METODE}

Desain penelitian yang diggunakan adalah quasi eksperimental dengan bentuk nonequivalent control group design yang memilih kelompok kontrol dan perlakuan tidak secara random. Pre-test dilakukan pada kedua kelompok dengan menggunakan kuesioner Indeks Kesiapan Fungsi Seksual Wanita dan evaluasi post-test dilakukan 3 minggu sesudahnya. Sampel pada penelitian ini adalah ibu prmipara yang telah melewati masa 3 minggu pascapersalinan normal di RSU Bangli Medika Canti Bali. Masing - masing kelompok terdiri dari 16 orang responden yang telah memenuhi kriteria inklusi. Pada kelompok perlakuan diberikan pelatihan senam kegel sehingga mampu melakukan latihan secara mandiri di rumah.

\section{HASIL}

Tabel 1. Hasil Uji Statistik Pengaruh Senam Kegel Terhadap Kesiapan Diri Secara Seksual Ibu Primipara Pada Kelompok Perlakuan Di Rumah Sakit Bangli Medika Canti Bali

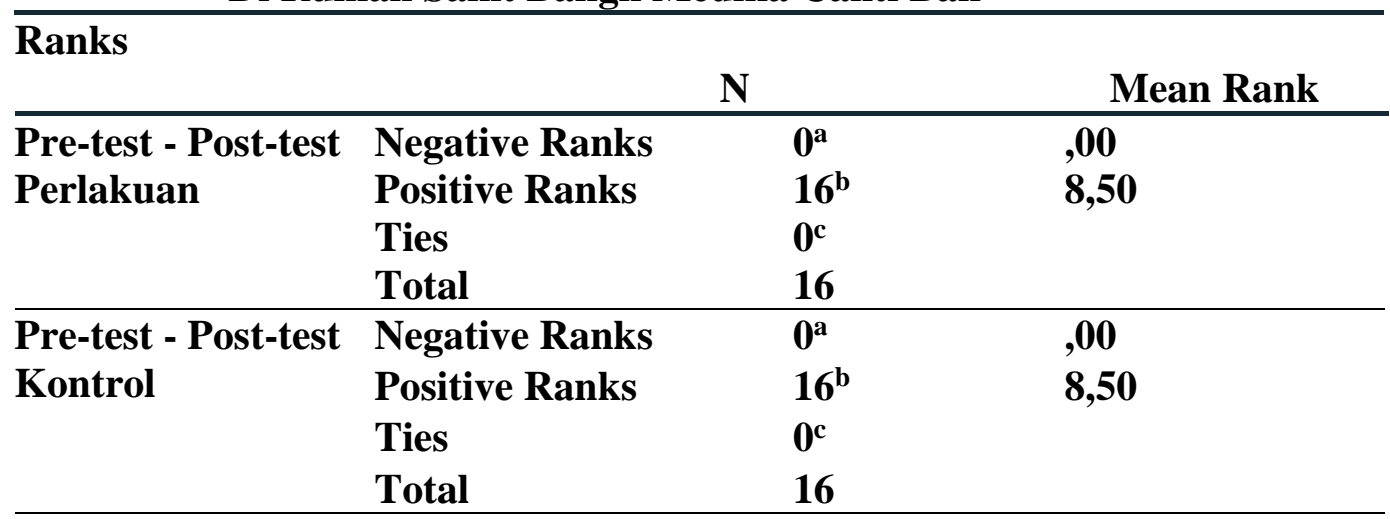

Nilai Z: $-\mathbf{3 , 5 1 7 ^ { \mathrm { b } }}$

Nilai Asymp. Sig. (2-tailed) : ,000 
Berdasarkan tabel 1. diatas pada kelompok perlakuan dapat diketahui bahwa nilai negative rank antara pre-test dan post-test pada kelompok perlakuan adalah 0 , begitu juga nilai kesamaan (ties). Sedangkan nilai positif rank adalah 16, yang artinya 16 responden mengalami peningkatan skor FSFI dari skor pre-test ke skor post-test. Sedangkan pada kelompok kontrol dapat diketahui bahwa nilai negative rank antara pre-test dan post-test pada kelompok kontrol adalah 0 , begitu juga nilai kesamaan (ties). Sedangkan nilai positif rank adalah 16, yang artinya 16 responden mengalami peningkatan skor FSFI dari skor pre-test ke skor post-test.

Tabel 2 Hasil Uji Statistik Perbedaan Kesiapan Diri Secara Seksual Ibu Primipara Pada Kelompok Perlakuan Dan Kontrol Di Rumah Sakit Bangli Medika Canti Bali

\begin{tabular}{llll}
\hline Ranks & Kelompok & N & Mean Rank \\
\hline Skor FSFI & Kelompok Perlakuan & $\mathbf{1 6}$ & $\mathbf{2 0 , 8 4}$ \\
& Kelompok Kontrol & $\mathbf{1 6}$ & $\mathbf{1 2 , 1 6}$ \\
& Total & 32 & \\
\hline Z & & & \\
Asymp. Sig. (2-tailed) & $\mathbf{- 2 , 6 2 7}$ & & \\
Exact Sig. [2*(1-tailed Sig.)] & $\mathbf{0 0 9}$ & &
\end{tabular}

Berdasarkan tabel 2. di atas diketahui nilai z= -2,911 dengan Asymp. Sig (0.09) <0,05, kesiapan seksual primipara dengan pelatihan memiliki nilai rerata 20,84 sedangkan pada kelompok tanpa senam kegel lebih kecil yaitu 12,16 yang artinya terdapat perbedaan yang signifikan antara kesiapan seksual primipara dengan latihan dan tanpa senam kegel.

\section{PEMBAHASAN}

Analisis Bivariat

Pengaruh Senam Kegel Terhadap Kesiapan Diri Secara Seksual Ibu Primipara Di Rumah Sakit Umum Bangli Medika Canti Bali.

Berdasarkan hasil penelitian ini dapat dilihat adanya peningkatan skor kesiapan seksual pada semua responden baik kelompok perlakuan maupun kelompok kontrol. Dari hasil uji mann whitney yang dilakukan, didapatkan hasil nilai rerata rank kesiapan seksual primipara dengan senam kegel adalah sebesar 20,84 sedangkan pada kelompok tanpa senam kegel nilai reratanya lebih kecil yaitu 12,16 nilai Asymp. Sig $0,009<\alpha(0,05)$. Secara statistik penelitian ini menunjukkan adanya pengaruh antara senam kegel terhadap kesiapan diri secara seksual ibu primipara, sehingga dapat dikatakan bahwa senam kegel mempengaruhi kesiapan seksual ibu primipara secara signifikan dibandingkan pada ibu primipara yang tidak melakukan senam kegel.

Senam kegel adalah senam yang bertujuan untuk memperkuat otot-otot dasar panggul terutama otot puboccygeal sehingga dapat memperkuat otot - otot di sekitar uretra dan otototot vagina yang dapat mengembalikan fungsi seksual. Senam kegel jika di lakukan secara teratur akan mendapatkan hasil yang maksimal. Latihan ini akan memperlihatkan manfaatnya jika dilakukan dalam waktu 8 - 12 kali perminggu, senam kegel juga dapat dirasakan perubahannya setelah 3 atau 4 minggu dengan berlatih beberapa menit setiap hari. Senam kegel memiliki variasi gerakan dan semua menggunakan prinsip yang sama yaitu melibatkan kontraksi berulang (pengetatan) dan merelaksasi (melepaskan) otot dasar panggul ( Sutanto, 2018)..

Selain itu senam kegel dapat meningkatkan tonus dan kekuatan otot lurik uretra dan periuretra. Manfaat latihan ini untuk meringankan berbagai gejala yang timbul akibat dari 
kelemahan otot dasar panggul seperti: stres saluran kencing, inkontinensia dan prolaps organ panggul, serta untuk meningkatkan respon seksual (Arsyad, Lotisna, \& Abdullah, 2012).

Penelitian oleh Golmakani et al., mengenai pengaruh senam kegel terhadap kesiapan seksual ibu primipara di Iran terhadap kelompok perlakuan dan kontrol dengan evaluasi dilakukan dalam waktu yang relatif lebih lama yaitu selama 8 minggu, menunjukkan peningkatan yang signifikan yaitu sebesar 13,7 setelah 8 minggu dimulainya penelitian pada perbandingan mean sebelum dan sesudah melakukan senam kegel (Golmakani et al, 2015). Penelitian oleh Dean et al., menunjukan bahwa ibu postpartum yang melakukan senam kegel memiliki fungsi seksual yang lebih baik. Penelitian tersebut dilakukan pada responden setelah enam tahun postpartum. Ibu yang melakukan senam kegel secara teratur mengalami peningkatan skor fungsi seksual. Hasil ini berarti bahwa senam kegel memberikan efek yang positif terhadap fungsi seksual perempuan( Dean et al, 2008, Lolowang, Nolla Lisa, 2017 ). Penelitian oleh Serati et al., tentang hubungan senam kegel terhadap fungsi seksual wanita pada pasien yang telah menyelesaikan senam kegel selama 3 bulan. Hasil penelitiannya menunjukan skor fungsi seksual wanita setelah melakukan senam kegel meningkat. Penelitian ini menunjukan bahwa latihan otot dasar panggul atau kegel dapat memperbaiki kesiapan seksual wanita( Serati et al 2015).

Peneliti memiliki asumsi bahwa senam kegel membantu memperkuat kembali otot dasar panggul serta saraf-saraf yang sebelumnya mengalami trauma akibat persalinan sehingga rasa nyeri lebih cepat hilang dan proses involusi organ reproduksi dapat berlangsung dengan baik sehingga mempengaruhi kesiapan seksual ibu pascamelahirkan. Senam kegel dapat dilakukan segera setelah persalinan ataupun menunggu kesiapan ibu untuk memulai aktivitas fisik kembali.

\section{KESIMPULAN}

Berdasarkan penelitian Pengaruh Senam Kegel Terhadap Kesiapan Diri Secara Seksual Ibu Primipara Di Rumah Sakit Umum Bangli Medika Canti Bali, didapatkan kesimpulan sebagai berikut :

a. Terdapat peningkatan kesiapan diri secara seksual pada keseluruhan kelompok responden yang melakukan senam kegel.

b. Terdapat peningkatan kesiapan diri secara seksual pada keseluruhan kelompok responden yang tidak melakukan senam kegel.

c. Ada perbedaan pengaruh yang signifikan dilakukannya senam kegel terhadap peningkatan kesiapan diri secara seksual ibu primipara. Hal ini terbukti melalui perbedaan rerata serta tingkat signifikansi perbandingan antar kelompok, nilai rerata kelompok dengan latihan adalah 20,84 dan kelompok tanpa latihan adalah 12,16 sedangkan nilai Asym. Sig 0,009 yang lebih kecil dari $\alpha(0,05)$ mencerminkan ibu primipara dengan latihan kegel lebih siap dalam memulai kembali kehidupan seksualnya.

\section{REFERENSI}

Adel, F., Fayiz F., Elshamy M. \& Hanf Y., 2010, The effect of pelvic floor exercise on sexual function after vaginal delivery, Med J Cairo Univ, 78, 27-31.

Arsyad E., Lotisna D. \& Abdullah Nusratuddin, 2012, Hubungan Senam Kegel terhadap Stres Inkontinensia Urin Postpartum pada Wanita Primigravida, Jurnal Obstetri dan Ginekologi Fakultas Kedokteran Universitas Hasanuddin, Makassar. 
Asselmann, Eva, Wittchen H., Erler L., \& Martini J., (2016), Peripartum changes in social support among women with and without anxiety and depressive disorders prior to pregnancy: a prospective-longitudinal study. Archives of Womens Mental Health, 19, 943-952.

Dean, N., Wilson D., Herbison P., Glazener C. Aung \& T. Macarthur C., 2008, Sexual function, delivery mode history, pelvic floor muscle exercises and incontinence: a cross-sectional study six years post-partum, Aust N Z J Obstet Gynaec, 48, 302-311.

Ferreira, Cristine \& Peter D., Melissa D., De Souza, Julio A., \& Helena F., 2015, Does pelvic floor muscle training improve female sexual function? A systematic review, International urogynecology journal, 26, 26, 1735-50.

Golmakani, N., Zahra Z., Nayereh K., Hossein S. \& Mohammad T.S., 2015, The effect of pelvic floor muscle exercises program on sexual self-efficacy in primiparous women after delivery, Iran J Nurs Midwifery Res, 20 (3), 347-353.

Leeman, Lawrence \& Rebecca Rogers, 2012, Sex After Childbirth Postpartum Sexual Function, Obstetrics and gynecology, 119, 647-55.

Lolowang, Nolla Lisa, 2017, Pengaruh Latihan Kegel Terhadap Sexual-Efficacy Ibu Postpartum, Tesis, Program Magister Fakultas Ilmu Keperawatan Universitas Indonesia, Depok.

Prawirohardjo, Sarwono, 2010, Ilmu Kebidanan Sarwono Prawirohardjo, PT. Bina Pustaka Sarwono Prawirohardjo, Jakarta.Sutanto, Andina Vita, 2018, Asuhan Kebidanan Nifas Dan Menyusui, PT. Pustaka Baru, Yogyakarta.

Serati, M., Braga A., DiDedda M.C., Sorice P., Peano E., Biroli A., Torella M., Cromi A., Uccella S., Salvatore S. \& Ghezzi F., 2015, Benefit of pelvic floor muscle therapy in improving sexual function in women with stress urinary incontinence: a pretest-posttest intervention study, J Sex Marital Ther, 41, 254-61.

Sutanto, Andina Vita, 2018, Asuhan Kebidanan Nifas Dan Menyusui, PT. Pustaka Baru, Yogyakarta. 